\title{
"... from teat-jerk to quidnunc": ARD Fairburn and the Formation of an Ideology of Architectural Nationalism in New Zealand
}

Peter Wood, Architecture, Victoria University, Wellington

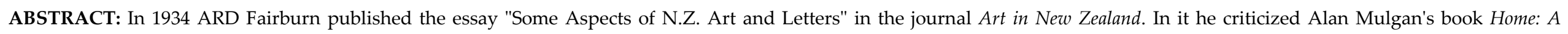

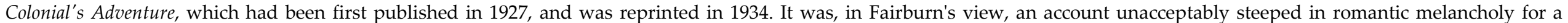
distant motherland that was no longer as germane as it had once been. Instead he proposed looking to the American Transcendentalists Twain and Thoreau for direction.

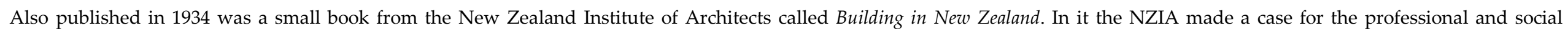

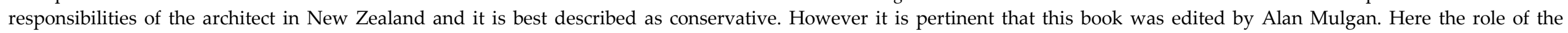

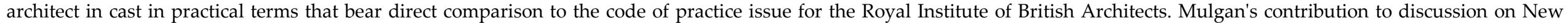

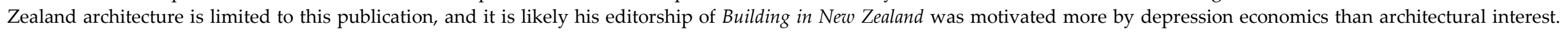

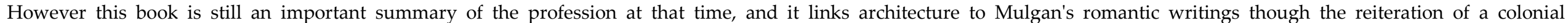

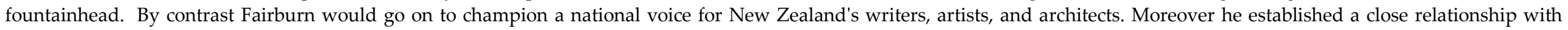

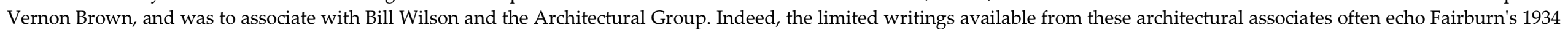
call for an antipodean "honesty" in "our" buildings.

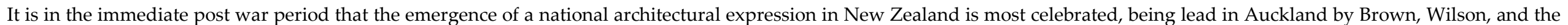

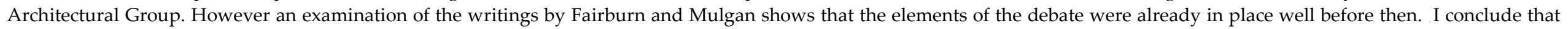

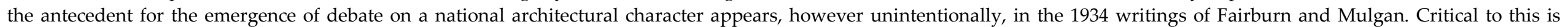
discussion on we mean by "honest" architectural work.

In 1934 ARD Fairburn published the essay "Some Aspects of N.Z. Art and Letters" in the journal Art in New Zealand. In it he criticized Alan Mulgan's book Home: A Colonial's Adventure, which had been published in 1927. It was, in Fairburn's view, an account unacceptably steeped in romantic melancholy for a distant motherland that was no longer relevant in the way that it had been. Gathering momentum, he criticised Mulgan for his sentimentality, writing:
The history of this country has been a progress from teat-jerk to quidnunc. A dark cloud of earnestness hangs over the land, and our young writers are industriously canvassing for outside aid. If we must be influenced from abroad (and we must), then let us see to it that our search is not led astray by prejudice and snobbery. Let us exercise intelligence and honesty. ${ }^{1}$

With only faint veiling Fairburn labels Mulgan a colonial snob, and then finishes by questioning his intellectual ability and, for effect, also his honesty. This is not to say that

${ }^{1}$ Fairburn "Some Aspects of N.Z. Art and Letters" p 218.
Mulgan did not offer Fairburn ammunition for such dismissal. Much of Home reads like a tourist guide to the sights of England, as Mulgan encountered them, and Fairburn's criticism that Mulgan had produced a "fullstop" on the subject of motherland is perhaps true. But his condemnation of the book as simplistic is disingenuous. Throughout Home Mulgan interprets his familiarity with so many names and places, much like any tourist travelling today, and while Mulgan found much to like about England his thoughts 
should be considered romantic rather than sentimental. The lasting impression is one of questions answered rather than identities confirmed. And while Home reflects Mulgan's anglophile tendencies he is not without criticism. It is, in Muglan's words, "primarily an attempt to interpret [England's] beauty, interest and maturity through a colonial's eyes."2 Indeed the full title of book - Home: A New Zealander's Adventure - could be interpreted not as an adventure in England but as an engagement with the idea of "home."

Understandably New Zealand's architecture suffers when compared to England's, but it is rare for Mulgan to make such a simplistic contrast, and mostly he describes the historic gravitas of England's ruins and cathedrals with a genuine sense of awe in the Old World. On the subject of farm houses he notes their grandeur and scale, but it is the picturesque relationship between house and landscape he enjoys. Here he does draw a contrast, calling New Zealand the land of galvanized iron, "which is probably the ugliest building material ever invented."3 There is little sympathy from Mulgan for any honesty

${ }^{2}$ Mulgan Home p 101.

${ }^{3}$ Mulgan Home p 86. inherent in the material fabric of a New Zealand house.

Further into Home he separates the house from the character of New Zealand with a comment that is as critical of English architectural traditions as anything Fairburn had to say:

"Was it not probable that behind the rough timber and iron of a raw New Zealand township there was a good deal more physical and mental vigour than in this decorous abode of age and tradition?" 4

However I do not think Mulgan is really speaking against historic ornamental practices. The house is used here as a useful metaphor for showing how easy it is to stereotype a society on cultural grounds. While Mulgan would probably have preferred New Zealand's houses that displayed a kinder relationship to the landscape I doubt he would have uncritically accepted a picturesque house in New Zealand as necessarily architecturally appropriate. His message is a more poignant reminder that national character, in people and buildings, is the product of complex influences, and superficial judgements are best avoided if it is to have integrity.

${ }^{4}$ Mulgan Home p 107.
Near the end of Home Mulgan reinforces this with a war anecdote. It concerns a New Zealand machine-gun officer who is asked to accompany a young British staff officer on an inspection of the New Zealand trenches. Responding to what Mulgan describes as one of "Mr Wodehouse's Piccadilly lizards," the Kiwi says to his mess: "Good lord, boys, look at what I've struck!" Mulgan continues:

However, duty called, so with heavy heart he took Bertie of Burlington up to the line. "I soon found," he said, "that what he did not know about that part of the line was not worth knowing, and during the round he unbuttoned his British "warm" and I found he was wearing the V.C, ribbon." 5

The Victoria Cross is the highest recognition of valour in the commonwealth armies, and just as corrugated iron can be, literally, an impoverished façade over a rich social interior, the stiff formalism of an English officer should not be used to judge his heart. It is a warning about building nationalism on reactionary stereotypes, and in this regard it is a prescient criticism of the kind of colonial snobbery that marks Fairburn's writing in We New Zealanders 17 years latter.

${ }^{5}$ Mulgan Home p 212. 
However Fairburn's criticism is about Mulgan's failure to appreciate an emergent New Zealand character as it is about the influences on character. Mulgan and Fairburn have a surprisingly similar sympathy for England, with both acknowledging the cultural and economic mass it provided through colonial expansion, but they are polarised over the future of this influence. Mulgan sees England as a prevailing identity from whose influence New Zealand needs to move on from in much the same way that a person leaves the home they grew up in without rejecting their parents.

By contrast Fairburn has seen another house that he wants to live in: that of "our eldest brother"6 - America. Using literature to illustrate his point, Fairburn advocates following American writing to show how New Zealand might throw off its colonial shackles to find a "true" literature tradition that is uniquely our own. Identifying what he calls "the true American style." Fairburn identifies Thoreau, Twain, Faulkner, and especially Hemingway, as models for what we might today call a post-colonial voice.

${ }^{6}$ Fairburn "Some Aspects of N.Z. Art and Letters" p 216.
Unfortunately he has nothing to say about architecture at this time, but I think it safe to assume that his approval for the paintings of Christopher Perkins for their "true and knowing expression of our landscape"7 indicates the type of opinion on nationalism that would have been an irresistible attraction to Vernon Brown's own views. Indeed, in "Bread for the People" (1946), ${ }^{8}$ Brown begins with an attack on aesthetic snobbery, "and the culture-mongering that goes with it," in a phrase that echoes Fairburn's writing in We New Zealanders two year earlier.

But if the English architect Brown found in Fairburn (a fourth generation New Zealander) a mode for all things New Zealand, then there is an echo to this. In 1939 Brown had made mention of the "illegitimate child" of Spanish Mission style housing which he saw as derivative. Then adds: "We seem to jump from the bits and piece of Tudor and Spanish to modern and ultra-modern overnight." 9 In Brown's opinion suburbia cannot tolerate sameness, and consequentially it is doomed to pursue the latest style regardless of regional influences: "There is a great desire to ape the

${ }^{7}$ Fairburn "Some Aspects of N.Z. Art and Letters" p 215.

${ }^{8}$ Brown "Bread for the People" p 20.

${ }^{9}$ Brown "Choose Your Style" p 34. architecture of other countries where other conditions obtain." 10

Brown lacks Fairburn's literary ability, but this argument reads like something Fairburn could have edited from "Some Aspects." In turn when Fairburn puts his attention to architecture in We New Zealanders, in 1944, it is with the same nationalist conviction found in "Some Aspects," but now thoroughly architectural rather than literary in its application. The parallels in their thinking are remarkable, to say the least. Here Fairburn writes on the suburb:

In the same way we build houses with sloping roofs, as our English ancestors did, so that the snow would slide off. And at the same time we superimpose Californian and pseudo-Spanish elements on our house-designs. ... In every way we show an ape-like capacity for copying overseas styles of behaviour, without modifying them to suit ourselves. ${ }^{11}$

This similarity in itself should not be surprising as Fairburn and Brown were good friends. But my feeling is that on the issue of New Zealand's architectural nationalism Brown and Fairburn had something of a codependent relationship. For Brown, Fairburn

${ }^{10}$ Brown "Choose Your Style" p 34.
${ }^{11}$ Fairburn We New Zealanders pp 8-9. 
offered indigenous pedigree, literary integrity and a mature intellectual position on where and how New Zealander's might draw their new influences. Conversely, Brown offered to Fairburn an opportunity to apply his thinking on nationalism to the practice of architecture whose monumental and symbolic value as a reflection of national identity has always been greater and more public than that of the other arts.

I suspect that Fairburn and Brown would have been inevitably drawn to each in Auckland's pre-war arts community, and in light of that it is interesting to think of the Architectural Group, and especially Bill Wilson, as the off-spring of an intellectual relationship that was consummated in the 1930s.

In 1935 Fairburn gave to Brown a satirical cartoon he had painted of Brown receiving a "Diploma for Best Design for Chicken Coop" from CR Ford of the dominant Auckland practice of the period, Gummer \& Ford. ${ }^{12}$ Peter Shaw suggests that Fairburn and Brown saw in Ford a symbol of the architectural

12 Illustrated in Shaw A History of New Zealand Architecture p 146. establishment that disapproved of Brown's houses. However it seems equally plausible that Fairburn and Brown saw in Reginald Ford a personification of the neo-classical work of Gummer \& Ford, which was so representative of the buildings Fairburn attacks in later writings. Yet this is despite Ford's colonial experiences as a volunteer on Robert Falcon Scott's Antarctic expedition of 1901-4, or Gummer's Beaux-Arts training and his association to the office of Edwin Lutyens in $1911 .{ }^{13}$ Softer in features and bearing than the angular Gummer, Ford would have been an easier target for the cartoonist's pen, but it may have been of some influence that with his long face, strong chin and large nose, Gummer looked like an older Fairburn. Whatever the case it was Ford who was privately lampooned for what Fairburn and Brown judged to be the crimes of a profession.

In 1946 Fairburn wrote the introduction to Planning, the magazine of the Architectural Group that promised so much but delivered only one issue. This commentary plainly reproduces the dominant themes Fairburn had outline more completely in We New Zealanders two years before. But at one point

${ }^{13}$ Lochhead "Gummer, William Henry 1884-1966" np. he writes curtly on what he calls the Gentleman architect:

To take off his coat and climb on a wall with a plumbline would so lower his dignity that he could no longer look the builder's apprentice in the eye. He loses sleep at night thinking of his six-and-a-half per cent. ${ }^{14}$

This last line is unmistakably taken from the cartoon Fairburn gave to Brown in which Ford resides over the awards ceremony as president of the "Six-And-A-Half Percent Club." Its rote use 11 years later suggests staleness on the part of Fairburn concerning his thinking on the matter of New Zealand architecture. Similarly his moralistic rhetoric concerning the importance of honesty and sanity in buildings can found in his criticisms of Mulgan.

In Fairburn's 1934 critique of Mulgan's Home there is meanness in the criticism that seems excessive, and that it came seven years after the first printing seems odd. Indirect accusations of prejudice and snobbery, and calls for intelligence and honesty are not just offensive, they are plainly unfair. After all, it has been Mulgan, in his capacity of literary

${ }^{14}$ Fairburn "[A Layman's View] By Way of Introduction" p 5 . 
editor at the Auckland Star, who had championed Fairburn's early writing.

But perhaps Fairburn's pettiness had something to do with the publication in that year of the New Zealand Institute of Architects (NZIA) booklet, Building in New Zealand, which Mulgan edited. ${ }^{15}$ On the whole the text of Building in New Zealand is innocuous enough. Its few literary pretensions are common references, and the only time any criticism is shown it is a general warning against the "overuse" of ornament and fussiness in domestic design. Otherwise it is a straightforward appeal for the value of the professional services of architects that left little room for offence.

However the captioned illustrations, although few, are another matter. One boasts the "air of comfort and restfulness" offered by a cottage with shutters and Welsh slate. There is a "pleasing design, based on English traditions," and another emphasises the material choice of terra-cotta tiles and brick walls. A fourth endorses adopting a Georgian character, and perhaps the most damning of all is the "rather unusual" house in the style of "Spanish

${ }^{15}$ Building in New Zealand.
Mission architecture of California," which the caption advocates as "quite appropriate for its location in the warm climate of the Auckland district." 16 These works are, then, exactly those that Brown would call "illegitimate" in 1939, ${ }^{17}$ and Fairburn would condemn as "vulgarity and cheap ostentation" in $1944 .^{18}$

How Mulgan came to be involved in this book is not clear, but I think it likely that it was a financial contingency at a time in his life when he was moving from newspaper journalism in Auckland to radio broadcasting in Wellington. ${ }^{19}$ It is also difficult to comment of what editorial influence he might have had although it seems reasonable to expect that others selected the photographs and Mulgan wrote the captions to suit. In any event Building in New Zealand must have popularised Mulgan as the voice of the NZIA, and therefore also all that Fairburn and Brown found offensive about New Zealand's architecture. In this context Fairburn's criticism of Home can interpreted as a way of condemning Building in New Zealand without risk of public censure, remembering that this

${ }^{16}$ Building in New Zealand $\mathrm{p} 20$.

${ }^{17}$ Brown "Choose your style" p 34.

${ }^{18}$ Fairburn We New Zealanders p 21.

${ }^{19}$ Jones "Mulgan, Alan Edward 1881-1962" np. was at a time when Fairburn was producing mocking cartoons of respected architects, and Brown was yet to establish his independent practice.

If so, it was a cowardly approach to challenging New Zealand's architectural orthodoxy, and grossly unfair to Home: A New Zealanders Adventure, which is a far more selfconscious examination of England than Fairburn ever allows. Home is a warning about developing colonial complacency by thinking of New Zealand's nationalism as everything that is not England's.

Curiously, Fairburn makes the same argument in both "Some Aspects" and We New Zealanders where he recognises the importance of balancing cultural independence against important international movements. In "Some Aspects" Fairburn counters his criticism of England with the confident view that America offers the best example of colonial independence. Yet by the time he writes We New Zealanders during the war he has become more circumspect, considering the replacement of English values with American ones as just another contrivance, and he carefully narrows the American model to what he calls "the native American tradition, 
which can be traced from Mark Twain right up to Errnest Hemingway."20

Hemingway is one of the most significant constants from "Some Aspects" to We New Zealanders. In the former he calls him " ... a true American, a colonial like ourselves, and closer to us than any Englishman."21 In the latter he uses the same quote from Jacobean poet, John Donne, that Hemingway used to begin For Whom the Bell Tolls:

"No man is an Island, intire of it selfe; every man is a peece of the continent, a part of the maine; if a clod bee washed away by the Sea, Europe is the Lesse, as well as it a Promontorie were, as well as if a Mannor of thy friends or of thine own were; any mans death diminishes me, becasue I am involved in Mankinde; and therefore never send to know who whom the bell tolls; it tolls for thee." 22

The allegorical message from Fairburn is on the necessity of understanding nationalism as a part of a greater larger human endeavour, and it may have appeared fateful to Fairburn that here was a passage that spoke so convincingly for one's place in the world in terms of islands. But it also betrays a

${ }^{20}$ Fairburn "Some Aspects of N.Z. Art and Letters" p 216.

${ }^{21}$ Fairburn "Some Aspects of N.Z. Art and Letters" p 217.

${ }^{22}$ Fairburn We New Zealanders p 11. melancholy for England and its writers as sentimental as anything he condemned Mulgan for in Home.

I also wonder how much influence Fairburn's interest in Hemingway might have exerted over other New Zealanders in their search for identity. Perhaps it was the Hemingway's presence that prompted Bill Wilson to volunteer for the Ambulance Corp in the Second World War just as Hemingway had served in it in The Great War?

One detail that is known is that John Mulgan, Alan Mulgan's son, took the title of his archetypal novel on New Zealand-ness - Man Alone (1939) - from Hemingway's to Have and Have Not. In the post-war reconstruction of New Zealand's architectural identity the image of the "Man Alone" has became a mythical figure for reasons that are not readily testable. ${ }^{23}$ Unfortunately this left behind the context Mulgan no doubt saw in of Hemingway's original phrasing: "'a man alone ain't got no bloody fucking chance,"'"24 a sentiment, I suspect, that the Architectural Group, despite their collective moniker, failed

${ }^{23}$ Clark and Walker Looking for the Local.

${ }^{24}$ Hemingway quoted, "Mulgan, John" p. 386. to appreciate when they fuelled themselves on the nationalistic speechifying of Fairburn and Brown and set out to sacrifice New Zealand's houses for the sins common to all suburban communities - "ill-planned, graceless and monotonous in their petty variety." 25

In Home, Alan Mulgan observes that the most precious quality of the Englishman is his sense of humour. ${ }^{26} \mathrm{He}$ does not say it directly but it is implied that the New Zealander is lacking in this regard. We probably still are. I certainly think that humour is glaringly absent from the rhetoric surrounding New Zealand's architectural nationalism. Fairburn's cartoon to Brown was not humorous but sarcastic.

As a departing gesture I wish to reflect on the title of this paper, which is one of Fairburn's more animated phrases in "Some Aspects on N. Z. Art and Letters": "... from teat-jerk to quidnunc." "Teat-jerk" should be read as a crude statement on New Zealand's nostalgic dependence on a Mother-England for cultural sustenance (even as we sent dairy products to them). At the time he wrote it, "quidnunc" was

${ }^{25}$ On the Necessity for Architecture p 1.

${ }^{26}$ Mulgan Home p 215. 
a phrase applied to gossips. Derived from the Latin quid nunc, or "what next," it is a term that immediately conjures the intrusiveness of one person's interest in another's business. The implication is two-fold: it can be taken as a principle for a country looking abroad for direction, or it could be an empty mantra for one without direction. Neither interpretation is particularly flattering.

Yet how close "what next" is to "what now" the stoic dictum of the greatest of all the neoclassicists, Alberti. As Mark Jarombek explains:

The question quid turn? ... represents the moment of shock that marks the transition from innocence to scepticism - from naivety to an understanding that the "Good Arts," the major ordering principle in society, have been irredeemably lost in the sewer. ${ }^{27}$

\footnotetext{
${ }^{27}$ Jarzombek On Leon Baptista Alberti pp 63-64.
} 


\section{REFERENCES}

Brown, Vernon "Bread for the People" Year Book of the Arts (1950) 6:20-21.

Brown, Vernon "Choose Your Style." The Monocle: The New Zealand Monthly Magazine (March 1939) 2(11):34-35,50.

Building in New Zealand: The architect and his service. ed. Alan Mulgan. Auckland, N.Z.: The New Zealand Institute of Architects, 1934.

Clark, J., and Walker, P. Looking for the Local: Architecture and the New Zealand Modern Wellington: Victoria University Press, 2000.

Fairburn, A.R.D. "[A Layman's View]By Way of Introduction" Planning: The Magazine of the Architectural Group (1946) 1:4-5.

Fairburn, A.R.D. "Some Aspects of N.Z. Art and Letters" Art in New Zealand (June 1934) VI(4):213-218.

Fairburn, A.R.D. We New Zealanders: An Informal Essay Wellington: Progressive Publishing Society, 1944.

Jarzombek, M. On Leon Baptista Alberti: His Literary and Aesthetic Theories. Cambridge, Massachusetts and London, England: The MIT Press, 1989.

Jones, Lawrence "Mulgan, Alan Edward 1881-1962" Dictionary of New Zealand Biography updated 7 April 2006. http://www.dnzb.govt.nz/

Lochhead, Ian J. "Gummer, William Henry 1884-1966" Dictionary of New Zealand Biography updated 7 April 2006. httpwww.dnzb.govt.nz/

Mulgan, Alan Home: A New Zealander's Adventure London: Longmans, Green and Co. Ltd., 1927.

On the Necessity for Architecture: The Manifesto of the Architectural Group Auckland: The Architectural Group, 1946.

"Mulgan, John" Roger Robinson and Nelson Wattie The Oxford Companion to New Zealand Literature Melbourne; Auckland: Oxford University Press, 1998:385-387.

Shaw, Peter A History of New Zealand Architecture 3rd ed. Auckland: Hodder Moa Beckett, 2003. 